\title{
Pengaruh Stres Kerja Dan Konflik Kerja Terhadap Kepuasan Kerja Pada PT. Sinarartha Bali Money Changer Kabupaten Badung
}

\author{
${ }^{1}$ Ary Wira Andika, ${ }^{2}$ Ni Putu Irmayanti \\ Universitas Mahasaraswati Denpasar, Bali, Indonesia \\ Email : ${ }^{1}$ arywira@unmas.ac.id, ${ }^{2}$ irmabiskuit777@gmail.com
}

(Diterima: Maret 2021; Direvisi: April 2021; Dipublikasikan: Mei 2021)

\begin{abstract}
ABSTRAK
Tujuan penelitian ini adalah untuk mengetahui pengaruh secara simultan dan parsial stres kerja dan konflik kerja terhadap kepuasan kerja pada PT. Sinarartha Bali Money Changer. Metode penelitian ini yaitu dengan cara observasi,wawancara, dan kuisioner. Kuisioner diberikan kepada 35 orang responden, alat analisis yang digunakan dalam penelitian ini adalah analisis regresi linier berganda, analisis korelasi berganda, analisis determinasi, F-test dan t-test. Hasil analisis diperoleh analisis regresi linier berganda $Y=42,221-0,276 X_{1}$ $0,484 \mathrm{X}_{2}$. Ini menunjukkan bahwa pola pengaruh stres kerja, konflik kerja terhadap kepuasan kerja adalah negatif. Artinya apabila stres kerja dan konflik kerja meningkat maka kepuasan kerja karyawan karyawan pada PT. Sinarartha Bali Money Changer akan menurun. Hasil analisis korelasi R sebesar 0,847, yang berarti terdapat hubungan yang sangat kuat antara stres kerja dan konflik kerja dengan kepuasan kerja karyawan. Hasil analisis determinasi diperoleh koefisien determinasi sebesar $71,7 \%$, ini berarti pengaruh stress kerja dan kepuasan kerja terhadap kepuasan kerja PT. Sinarartha Bali Money Changer sebesar 71,7\% sedangkan sisanya sebesar 28,3\% dipengaruhi oleh faktor lain diluar penelitian ini.4) Dari hasil analisis $\mathrm{F}$ test diperoleh nilai signifikasi $\mathrm{Fl}=$ hitung $0,000<0,05$, ini berarti bahwa stres kerja dan kepuasan kerja berpengaruh signifikan secara simultan terhadap kepuasan kerja karyawan. 5) Hasil uji t-test stres kerja diperoleh nilai signifikan sebesar $0,005<0,05$, maka dapat disimpulkan bahawa stres kerja berpengaruh negatif dan signifikan terhadap kepuasan kerja karyawan. Demikian juga konflik kerja berpengaruh negatif dan signifikan terhadap kepuasan kerja karyawan pada PT. Sinarartha Bali Money Changer.
\end{abstract}

\section{Kata Kunci : Stres Kerja, Konflik Kerja, dan Kepuasan Kerja Karyawan.}




\section{PENDAHULUAN}

Sumber daya manusia merupakan modal utama dalam merencanakan, mengorganisir, mengarahkan serta menggerakkan sumber daya lainnya yang ada dalam suatu organisasi Potale dan Uhing (2015:64). Dalam manajemen sumber daya manusia terdapat sasaran utama yaitu upaya perusahaan meningkatkan kepuasan kerja karyawan. Kepuasan kerja karyawan merupakan salah satu aspek penting yang perlu diperhatikan dalam usaha peningkatan kemampuan sumber daya manusia suatu organisasi, karena dengan kepuasan kerja yang dirasakan maka seorang karyawan mampu bekerja secara optimal menurut Nilvia (Ramadanu 2016:3). menurut Rivai (Afrizal dkk, 2014:4) kepuasan kerja merupakan evaluasi yang menggambarkan seseorang atas perasaan sikapnya, senang atau tidak senang, puas atau tidak puas dalam bekerja. Stres kerja adalah suatu kondisi ketegangan yang meciptakan adanya ketidakseimbangan fisik dan psikis yang mempengaruhi emosi, proses berfikir dan kondisi seorang karyawan Rivai (Afrizal dkk, 2014). Definisi tersebut sejalan dengan yang diungkapkan oleh Handoko (Afrizal dkk,2014) bahwa stres adalah suatu kondisi ketegangan yang mempengaruhi emosi, proses berpikir dan kondisi seseorang dalam melaksanakan pekerjaannya. Dampak stres pada kepuasan kerja dapat langsung terjadi. Umar (2009) meyatakan stres mempunyai potensi untuk mengganggu kepuasan kerja karyawan tergantung dari berapa tingkat stres. Hal ini sejalan dengan penelitian yang dilakukan oleh Afrizal dkk (2014) yang menemukan bahwa stres kerja berpengaruh negatif dan signifikan terhadap kepuasan kerja karyawan. Penelitian dari Poniasih dan Dewi (2015) menemukan bahwa stres kerja berpengaruh negatif dan signifikan terhadap kepuasan kerja karyawan. Selain itu yang dapat mengakibatkan stres adalah konflik Afrizal dkk (2014:2). Konflik di dalam pekerjaan juga di sebut segala macam interaksi pertetangan atau antagonistik antara dua orang atau lebih di dalam perusahaan. Konflik di dalam kegiatan perusahaan timbul karena adanya kenyataan bahwa mereka harus membagi sumber daya, sumber daya yang terbatas atau kegiatan kegiatan kerja dan adanya kenyataan bahwa mereka mempunyai perbedaan status, tujuan dan nilai persepsi. Menurut Winardi (Afrizal dkk, 2014) menyatakan konflik merupakan situasi, dimana terdapat berbagai tujuan atau berbagai emosi yang tidak sesuai satu sama lain, pada diri beberapa individu yang kemudian menyebabkan timbulnya pertentangan. Hal ini sejalan dengan penelitian yang dilakukan oleh Ramadanu (2016) dari hasil penelitian menunjukkan bahwa konflik kerja berpengaruh signifikan terhadap kepuasan kerja karyawan. Serta dari hasil penelitian dari Han dan Netra (2013) yang menyatakan konflik kerja berpengaruh negatif terhadap kepuasan kerja karyawan. Nilai negatif mennjelaskan adanya pengaruh yang tidak searah yaitu apabila konflik meningkat maka kepuasan kerja karyawan akan menurun.

Melihat fenomena yang terjadi mengenai Pengaruh Stres Kerja dan Konflik Kerja seperti yang telah 
dipaparkan, maka penulis tertarik melakukan penelitian dengan judul "Pengruh Stres Kerja dan Konflik Kerja Terhadap Kepuasan Kerja Karyawan Pada PT. Sinarartha Bali Money Changer".

\section{TINJAUAN PUSTAKA}

\section{Stres Kerja}

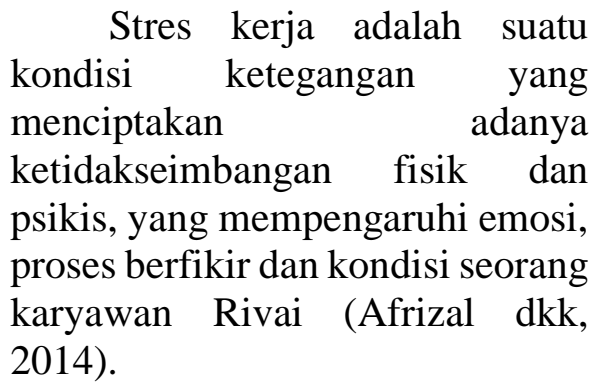

Menurut Cooper (Devi,2018), bahwa Indikator stres kerja ada empat, yaitu sebagai berikut:

a. Kondisi Pekerjaan

1) Overload

2) Deprivational

stress. Kondisi pekerjaan tidak lagi menantang, atau tidak lagi menarik bagi karyawan

3) Pekerjaan beresiko tinggi.

b. Konflik Peran

c. Pengembangan Karir

d. Struktur Organisasi

\section{Konflik Kerja}

Menurut Winardi (Afrizal dkk, 2014) menyatakan konflik merupakan situasi, dimana terdapat berbagai tujuan atau berbagai emosi yang tidak sesuai satu sama lain, pada diri beberapa individu yang kemudian menyebabkan timbulnya pertentangan. Sunyoto dan Burhanudin (Septriani,2016) konflik yang terjadi antar kelompok dalam organisasi disebabkan oleh banyak sebab. Indikator-indikator utama penyebab konflik antar kelompok antara lain :

a. Ketergantungan kerja/work interdependence.

1) Ketergantungan berkelompok (pooled interpendence)

2) Ketergantungan berurutan (sequential interdependence)

3) Ketergantungan timbal balik(reciprocal interpendence)

b. Perbedaan tujuan

c. Perbedaan persepsi

d. Kemenduaan organisasional

\section{Kepuasan Kerja}

Menurut Rivai (Afrizal dkk, 2014:4) kepuasan kerja merupakan evaluasi yang menggambarkan seseorang atas perasaan sikapnya, senang atau tidak senang, puas atau tidak puas dalam bekerja. Luthan (Santiari,2018) mengemukakan Job Descriptive Index (JDI) indikator yang dapat digunakan untuk mengukur kepuasan kerja,yaitu:

a. Kesesuaian antara Ketrampilan dan Tugas

b. Insentif

c. Karir

d. Pendamping Atasan

e. Tim Kerja ( Team Work)

\section{METODE PENELITIAN}

Penelitian ini dilaksanakan di PT. Sinarartha Bali Money Changer yang terletak di jalan By Pass Ngurah Rai No 11 G, Kuta, Badung. Latar belakang pemilihan lokasi ini karena ditemukan masalah berkaitan dengan stres kerja dan konflik kerja terhadap kepuasan kerja karyawan pada PT. Sinarartha Bali Money Changer.

\section{Obyek Penelitian}

Penelitian ini mengambil objek pengaruh stres kerja dan konflik kerja, terhadap Kepuasan 
kerja karyawan pada PT. Sinarartha Bali Money Changer.

\section{Identifikasi Variabel}

\section{Menurut Sugiyono,} (2012:60), variabel penelitian pada dasarnya adalah segala sesuatu yang berbentuk apa saja yang ditetapkan oleh peneliti untuk dipelajari sehingga diperoleh informasi tentang hal tersebut, kemudian ditarik kesimpulannya.

Dalam penelitian ini terdapat dua jenis variabel yang diteliti yaitu:

a. Variabel bebas atau independent variable, yaitu variabel yang mempengaruhi atau yang menjadi sebab perubahan atau timbulnya variable terikat. Dalam penelitian ini yang menjadi variable bebas adalah Stres Kerja (X1) dan Konflik Kerja (X2)

b. Variabel terikat atau dependent variable, yaitu variabel yang dipengaruhi atau menjadi akibat karena adanya variable bebas. Dalam penelitian ini yang menjadi variabel terikat adalah Kepuasan kerja Karyawan (Y).

\section{Definisi Operasional Variabel}

a. Variabel Stres Kerja diukur dengan beberapa indikator yaitu: Kondisi Pekerjaan

(Overload, Deprivational stres, Pekerjaan beresiko tinggi), Konflik Peran, Pengembangan Karir, Struktur Organisasi

b. Variabel Konflik Kerja diukur dengan beberapa indikator yaitu: Ketergantungan kerja/work interdependence (Ketergantungan berkelompok, Ketergantungan berurutan Ketergantungan timbal balik),
Perbedaan tujuan, Perbedaan persepsi, Kemenduaan organisasional.

c. Variabel Kepuasan diukur dengan beberapa indikator yaitu: Kesesuaian antara Ketrampilan dan Tugas, Insentif, Karir, Pendamping Atasan, Tim Kerja ( Team Work ).

\section{Populasi dan Sampel}

Populasi adalah wilayah generalisasi yang terdiri atas objek/subyek yang mempunyai kualitas dan karakteristik tertentu yang ditetapkan oleh peneliti untuk dipelajari dan kemudian ditarik kesimpulanya (sugiyono, 2002:55). Populasi dalam peneliti ini adalah seluruh karyawan PT. Sinarartha Bali Money Changer yang berjumlah 35 orang.

Sugiyono

(2014:116), sampel adalah bagian dari jumlah dan karakteristik yang dimiliki oleh populasi tersebut. Mengenai jumlah populasi pegawai yang akan diambil dalam penelitian. Sampel merupakan wakil dari populasi, apabila subyeknya kurang dari 100, lebih baik diambil semua sehingga penelitiannya merupakan penelitian populasi. Selanjutnya jika jumlah subyeknya besar, dapat diambil antara 10\% $15 \%$ atau $20 \%$ - 25\% atau lebih (Arikunto,2006:112). Dalam penelitian ini, mengingat jumlah populasi 35 orang, maka seluruh populasi dijadikan sampel, yang disebut dengan penelitian sensus.

\section{Teknik Analisis Data}

Teknik analisis data yang digunakan dalam penelitian ini adalah analisis linier berganda, 
analisis data berpedoman pada yang diukur menggunakan skala likert. Tahapan analisis terdiri dari

a. Uji Instrumen Penelitian

b. Deskripsi Variabel Penelitian

c. Uji Asumsi Klasik

d. Analisis Kuantitatif

Analisis regresi linier berganda digunakan untuk melihat pengaruh variabel stres kerja dan konflik kerja terhadap kepuasan kerja karyawan, model persamaan analisis regresi linier berganda dalam penelitian ini adalah sebaggai berikut:

Rumus Regresi Linier Berganda

$$
\left.\left.Y=\alpha+\beta^{\prime} X^{\prime}+\beta\right) X\right)+\varepsilon
$$

\section{HASIL DAN PEMBAHASAN}

1. Pengaruh Variabel Stress Kerja Terhadap Kepuasan Kerja

Dari uji regresi linear berganda diperoleh koefisien regresi variabel stress kerja (X1) sebesar -0,276 dan uji t variabel stress kerja (X1) memiliki nilai t.hitung negatif sebesar -3.056 dengan nilai Sig. sebesar 0,005 < 0,05 . Hasil ini berarti variabel stress kerja berpengaruh negatif dan signifikan terhadap kepuasan kerja sehingga $\mathrm{H} 1$ diterima. Hal ini berarti jika karyawan mengalami stress kerja pada PT. Sinarartha Bali Money Changer maka dapat menurunkan kepuasan kerja karyawan. Ini sesuai dengan penelitian sebelumnya ditemukan oleh Afrizal dkk (2017) menunjukkan bahwa stres kerja berpengaruh negatif dan signifikan terhadap kepuasan kerja. Hasil penelitian tersebut juga didukung oleh penelitian dari Serta hasil penelitian dari Poniasih dan Dewi
(2015) menemukan bahwa stres kerja berpengaruh negatif dan signifikan terhadap kepuasan kerja karyawan. Ini berarti jika stres kerja meningkat maka kepuasan kerja akan menurun.

2. Pengaruh Variabel Konflik Kerja Terhadap Kepuasan Kerja

Dari uji regresi linear berganda diperoleh koefisien regresi variabel konflik kerja (X2) sebesar $-0,484$ dan uji t variabel konflik kerja (X2) memiliki nilai t.hitung negatif sebesar $-6,470$ dengan nilai Sig. sebesar $0,000<$ 0,05 . Hasil ini berarti variabel konlik kerja berpengaruh negatif dan signifikan terhadap kepuasan kerja sehingga $\mathrm{H} 2$ diterima. Hal ini berarti jika karyawan mengalami konflik kerja pada PT. Sinarartha Bali Money Changer maka dapat menurunkan kepuasan kerja karyawan. Ini sejalan dengan hasil pnelitian yang dilakukan oleh oleh Ramadanu (2016) konflik kerja berpengaruh signifikan terhadap kepuasan kerja karyawan. Serta penelitian dari Han dan Netra (2013) yang menyatakan konflik kerja berpengaruh negatif terhadap kepuasan kerja karyawan Ini artinya jika konflik kerja meningkat makan kepuasan kerja karyawan akan menurun.

3. Pengaruh Variabel Stres Kerja dan Konflik Kerja Terhadap Kepuasan Kerja

Berdasarkan uji $\mathrm{R}$ dapat dilihat variabel stress kerja dan konflik kerja secara bersama menunjukan berpengaruh signifikan dan negatif terhadap kepuasan kerja karyawan. Hal ini dibuktikan dengan nilai koefisien 
determinasi sebesar $71,7 \%$ dan sisanya $28,3 \%$ dipengaruhi oleh variabel lain yang tidak masuk dalam penelitian ini. Jika salah satu dari variabel mengalami kenaikan, maka secara tidak langsung berpengaruh terhadap kepuasan kerja karyawan pada PT. Sinarartha Bali Money Changer, begitu juga sebaliknya. Hal ini dibuktikan dengan nilai $F_{\text {hitung }}$ positif sebesar 40.601 dengan Sig. $0,000<(\alpha)=0,05$ yang menunjukkan bahwa ada pengaruh signifikan secara simultan antara Stres Kerja dan Konflik Kerja terhadap Kepuasan Kerja Karyawan, sehingga H3 diterima. Hal ini didukung oleh penelitian yang dilakukan oleh Azhar (2017) yang menemukan konflik kerja dan stres kerja berpengaruh secara simultan terhadap kepuasan kerja karyawan. Pendapat ini didukung oleh hasil temuan Afrizal dkk (2014) yang menemukan terdapat pengaruh secara simultan yang signifikan antara konflik kerja dan stres kerja terhadap kepuasan kerja karyawan. Serta penelitian Ramadanu (2016) yang menemukan bahwa stres kerja dan konflik kerja berpengaruh signifikan secara simultan terhadap kepuasan kerja.

\section{KESIMPULAN DAN SARAN}

\section{A. Kesimpulan}

Berdasarkan hasil analisis data dan pembahasan, maka dapat ditarik simpulan hasil penelitian adalah sebagai berikut.

1. Stres Kerja berpengaruh negatif dan signifikan terhadap Kepuasan Kerja Karyawan pada PT. Sinarartha Bali Money
Changer. Hal ini berarti apabila stres kerja meningkat maka kepuasan kerja pada PT. Sinarartha Bali Money Changer akan menurun.

2. Konflik Kerja berpengaruh negatif dan signifikan terhadap Kepuasan Kerja Karyawan pada PT. Sinarartha Bali Money Changer. Hal ini berarti apabila konflik kerja meningkat maka kepuasan kerja pada PT. Sinarartha Bali Money Changer akan menurun.

3. Stres Kerja dan Konflik Kerja signifikan berpengaruh secara simultan terhadap Kepuasan Kerja Karyawan pada PT. Sinarartha Bali Money Changer. Ini berarti jika Stres kerja dan Konflik kerja meningkat maka Kepuasan Kerja pada PT. Sinarartha Bali Money Changer akan menurun

\section{B.Saran}

Berdasarkan hasil penelitian dan kesimpulan yang telah dibuat maka saran yang dapat diajukan berkaitan dengan stress kerja dan konflik kerja terhadap kepuasan kerja pada PT. Sinarartha Bali Money Changer sebagai berikut:

1. Berdasarkan rata - rata skor pada variabel stres kerja dimana secara keseluruhan responden mempunyai persepsi yang paling rendah pada item pertanyaan yaitu pekerjaan yang beresiko tinggi yang dapat membahayakan membuat karyawan menjadi stres, maka sebaiknya perusahaan meningkatkan keamanan agar tidak terjadinya resiko yang berbahaya bagi karyawan 
2. Berdasarkan rata - rata skor pada variabel konflik kerja dimana secara keseluruhan responden mempunyai persepsi yang paling rendah pada item pertanyaan yaitu setiap kelompok melakukan pekerjaan secara terpisah sementara setiap kinerja kelompok menentukan kesuksesan organisasi, hal ini dapat menimbulkan konflik, maka perusahaan sebaiknya memotivasi semua karyawan agar terciptanya kerja team(team work) guna tercapainya kesuksesan organisasi.

3. Berdasarkan rata - rata skor pada variabel kepuasan kerja dimana secara keseluruhan responden mempunyai persepsi yang paling rendah pada item pertanyaan yaitu setiap karyawan merasa puas jika karir mereka meningkat, maka, sebaiknya perusahaan memberikan kesempatan bagi karyawannya untuk mengembangkan karirnya.

\section{DAFTAR PUSTAKA}

Afrizal, Poundra Rizky dkk.(2014).Pengaruh Konflik Kerja Dan Stres Kerja Terhadap Kepuasan Kerja.Studi Pada Karyawan PT. TASPEN (PERSERO) Cabang Malang. Jurnal Fakultas Ilmu Administrasi Universitas Brawijaya Malang.Vol. 8 No. 1. Arikunto, S. (2010). Prosedur Penelitian suatu Pendekatan Praktik. Jakarta: RinekaCipta.

Azhar, Ahmad.(2017). Pengaruh Konflik Kerja dan Stres Kerja Terhadap Kepuasan Kerja Karyawan Badan Kependudukan dan Keluarga Berencana Nasional Kabupaten Enrengkang.Skripsi
Jurusan Manajemen Fakultas Ekonomi Dan Bisnis Islam Universitas Islam Negeri Alauddin Makassar.

Cooper dalam Jacinta F. (2002). Stres Kerja. Team e-psikologi.com. Retrivied from http://www.baliusada.com/cont ent/view/333/2/, diakses $2 \mathrm{Mei}$ 2015.

Devi, Ni Komang Sri. (2018). Pengaruh Lingkungan Kerja Fisik Dan Stres Kerja Terhadap Kinerja Karyawan Pada PT. BPR Tridarma Putri Semarapura Klungkung. Skripsi Jurusan Manajemen Fakultas Ekonomi Universitas Mahasaraswati Denpasar.

Dewi, Ni Putu Enika Lestari, dan I Gusti Salit Ketut Netra.(2015). Pengaruh Stres Kerja Dan Motivasi Kerja Terhadap Kepuasan Kerja Karyawan Pada Matahari Bungalow Restaurant And SPA Legian Kuta-Bali. E-Jurnal Manajemen Fakultas Ekonomi dan Bisnis Universitas Udayana. Vol. 4, No. 7, $1933-$ 1948 ISSN: 2302-8912.

Elfianto.(2017). Pengaruh Stres Kerja dan Kualitas Kerja Terhadap Kepuasan Kerja Polisi Polresta Padang. Studi Kasus Polisi Berpangkat Bintara. Jurnal Manajemen dan Kewirausahaan Program Studi Manajemen Fakultas Ekonomi Unitas Padang. Volume 8, Nomor 3.

Ghozali, Imam. (2012). Aplikasianalisis Multivariate dengan Program IBM SPSS. Yogyakarta: Universitas Diponogoro. 
Ghozali, Imam. (2016). Aplikasi Analisis Multivariete Dengan Program IBM SPSS 23 (Edisi 8). Cetakan ke VIII. Semarang : Badan Penerbit Universitas Diponegoro.

Han, Che dan I Gusti Salit Ketut. (2013). Pengaruh Konflik Terhadap Stres Kerja Dan Kepuasan Kerja Karyawan. Jurnal Fakultas Ekonomi dan Bisnis Universitas Udayana.

Handoko, T. H. (2001). Manajemen Personalia dan Sumber Daya Manusia. Edisi 2.Cetakan kelimabelas. Yogyakarta: BPFE.

Handoko, T. Hani. (2000). “ Manajemen Sumber Daya Manusia”. Yogyakarta: BPFE.

Kombong, Agustina. (2015). Pengaruh Lingkungan Kerja,Dan Stres Kerja Terhadap Kepuasan Kerja Pegawai Fakultas Keguruan Dan Ilmu Pendidikan Universitas Tadulako. Jurnal Program Studi Magister Manajemen Pascasarjana Universitas Tadulako. E-Jurnal Katalogis, Volume 3 Nomor 10.Hlm 13714.

Luthans, dalam Triton PB. (2009). Manajemen dalam Persepektif Partnershif dan Kolektivitas. Yogyakarta : Oryza

Mangkunegara, A.A.P. (2007). Manajemen Sumber Daya Manusia Perusahaan. Cetakan kesembilan. Bandung: PT. Remaja Rodaskarya Offset.

Martoyo, S. (2000). Manajemen Sumber Daya Manusia Edisi 4. BPFE, Yogyakarta

Minarsih, Maria Magdalena. 2009. Konflik Kerja, Stres Kerja dan
Cara Mengatasinya. Jurnal Fakultas Ekonomi Universitas Pandanaran Semarang.

Muhamad Agus Rakhman, Masjaya, Sugandi. (2013). Faktor-Faktor yang Mempengaruhi Kepuasan Kerja Pegawai pada Dinas Perhubungan Provinsi Kalimantan Timur. Journal Administrative Reform, 1(1):316-327.

Mulyadi dan Rivai. (2003). Manajemen Sumber Daya Manusia, Jakarta: cetakan Kesembilan.

Nurjaya, N., Sunarsi, D., Effendy, A. A., Teriyan, A., \& Gunartin, G. (2021). Pengaruh Etos Kerja Dan Disiplin Kerja Terhadap Kinerja Pegawai Pada Dinas Kehutanan Dan Perkebunan Kota Bogor. JENIUS (Jurnal Ilmiah Manajemen Sumber Daya Manusia), 4(2), 172-184.

Poniasih,Ni Luh Gede dan A.A.Sagung Kartika Dewi.(2015). Pengaruh Motivasi Kerja, Komunikasi Dan Stres Kerja Terhadap Kepuasan Kerja Karyawan. Jurnal Manajemen Fakultas Ekonomi Dan Bisnis Universitas Udayana.Vol. 4, No. 6,1560-1573

Rahim, M. A. (2011). Managing conflict in organizations (3rd ed.). Westport: Greenwood Publishing Group, Inc.

Rivai, V. dan E.J. Sagala. (2010). Manajemen Sumber Daya Manusia untuk Perusahaan: Dari Teori ke Praktik. Edisi 2. Jakarta: Rajawali Pers.

Robbins SP, dan Judge. (2016). Prilaku Organisasi Buku 2, 
Jakarta : Salemba Empat.Hal 429.

Robbins, Stephen P. dan Timothy A. Judge. (2008). Perilaku Organisasi Edisi ke-12, Jakarta: Salemba Empat.

Rose, Vasse Joy. (2010). Journal of Applined Management and Entrepreneurship : Monetary Motivation, Performance and Job Satisfaction.

Sankul Edy. (2011). Manajemen Sumber Daya Manusia. Jakarta : Kencana.

Santiari, Ni Wayan. (2018). Pengaruh Kepemimpinan dan Lingkungan Kerja Terhadap Kepuasan Kerja Karyawan PT. Sinar Sosro KP. Tabanan Di Desa Werdi Bhuana. Skripsi Jurusan Manajemen Fakultas Ekonomika dan Humaniora Universitas Dhyana Pura Badung.

Sekaran, Uma. (2011). Metode Penelitian Untuk Bisnis. Jakarta: Salemba Empat.

Septriani, Ni kadek Sri.(2016). Pengaruh Budaya Organisasi dan Konflik Kerja terhadap Kinerja Karyawan Pada Koperasi Simpan Pinjam (KSP)
Sari Permata Niaga Kerobokan Kuta Badung. Skripsi Program Studi Manajemen Universitas Mahasaraswati Denpasar.

Sinambela. (2016). Reformasi Pelayanan Publik. Jakarta; Bumi Aksara.

Sugiyono. (2017). Metode Penelitian Kuantitatif, Kualitatif dan R\&D. Bandung: Alfabeta.

Sukmadinata, Nana S. (2010). Metode Penelitian Pendidikan. Cetakan ke-4. Bandung: PT. Remaja Rosdakarya.

Sunyoto, Danang dan Burhanudin. (2011). Prilaku Organisasi. Yogyakarta : CAPS.Edy Sankul, 2011, Manajemen Sumber Daya Manusia, Jakarta : Kencana.

Umar, Husein. (2009). Riset Sumber Daya Manusia Dalam Organisasi. Jakarta: PT Gramedia Pustaka Utama.

Winardi. (2004). Manajemen Perilaku Organisasi. Jakarta: Pustaka Binaman Pressindo.

Wirawan, Nata. (2002). Cara Mudah Memahami Statistik 2, Edisi Kedua, KerarasEmas, Denpasar. 